\title{
Nuevas formas de leer. Diccionario de conceptos clave de lectura y escritura'
}

Como anunciábamos en el número anterior este Diccionario de conceptos clave de lectura y escritura es una obra colectiva en la que colaboran más de 70 especialistas que forman parte de la Red Internacional de Universidades Lectoras (RIUL), dirigida por Eloy Martos ${ }^{2}$.

Iniciamos con estos 10 conceptos la presentación de "Términos escogidos" que queremos ir realizando en sucesivos números. Cada una de las entradas del diccionario está acompañada de una breve lista de términos relacionados, y en general incluyen tres apartados: "Definición, antecedentes y actualidad del término"; "Análisis" y "Aplicaciones prácticas". Finalmente se ofrece una bibliografía cuya presentación responde a la que tiene la obra completa y que aparece desarrollada al final de la misma.

- Alfabetización visual (Amando López Valero [A.L.V] e Isabel Jerez Martínez [I.J.M.])

- Bibliotecas escolares (Carmen Agustín Lacruz [C.A.L.] y Begoña Gimeno Arlanzón[B.G.A.])

- Clásicos (María Elena Fonsalido [M.E.F.])

- Ciberliteratura (Isabel Morales Sánchez [I.M.S.])

- Edición en La nube (José Antonio Cordón García [J.A.C.G.] y Raquel Gómez Díaz[R.G.D.])

- Estratégias de leitura (Renata Junqueira [R.J.])

- Fonología y fonética (Sara Robles Ávila [S.R.A.])

- Gestión Cultural (Héctor Pose Porto [H.P.P.])

- Traducción (Josep Ballester [J.B.R.] y Noelia Ibarra [N.I.R.])

- Valores y lectura (Santiago Yubero [S.Y.], Sandra Sánchez García [S.S.G.] y Elisa Larrañaga [E.L.])

\footnotetext{
I Para citar este artículo: Campos F.Fígares, M., (selec.) Nuevas Formas de leer. Términos escogidos i. Álabe 6, [www.revistaalabe.com] (Recibido I4-I2-2OI2; aceptado 27-I2-2OI2)

${ }^{2}$ Vid. Martos, E. y Campos, M. La lectura y la escritura en el s.XXI: Cultura letrada y modernidad. Alabe 5 , junio 2012 [http://www.ual.es/alabe]
} 


\section{Alfabetización visual}

[Comunicación visual / Literacidad]

\section{- Definición, antecedentes y actualidad del término}

El término "alfabetización visual” fue acuñado en I968 por John Debes, una de las figuras más importantes en la historia de la Asociación Internacional de Alfabetización Visual. La definición del término es la siguiente:

La alfabetización visual se refiere a un grupo de competencias visuales que un ser humano puede desarrollar y, al mismo tiempo adquiere por la integración de otras experiencias sensoriales. El desarrollo de estas competencias es fundamental para el normal aprendizaje del ser humano. Una vez desarrolladas, éstas, permiten a una persona alfabetizada visualmente el poder discriminar e interpretar las acciones visuales, los objetos, los símbolos, naturales o los provocados por el hombre, que se encuentran en su medio ambiente. A través del uso creativo de estas competencias, una persona es capaz de comunicarse con los demás. A través del uso concreto y consciente de estas competencias, una persona también es capaz de comprender y disfrutar de las obras maestras de la comunicación visual.

Sin embargo, podemos plantear más definiciones del término como la adquisición de conocimientos y experiencias sobre las producciones de los medios de comunicación visuales junto con una creciente y consciente concienciación de esas realizaciones visuales. De hecho, cada estudioso de la alfabetización visual ha producido la suya propia. Es comprensible, por tanto, una coexistencia de muchas disciplinas que se encuentren en la base del concepto de Alfabetización Visual; algo que provoca y, al mismo tiempo, enfatiza el carácter ecléctico de la misma. Esto constituye también el principal obstáculo para lograr una definición unánime del término.

Hay muchas definiciones de alfabetización visual: desde las definiciones complejas que ponen de manifiesto las habilidades necesarias para sobrevivir en el siglo XXI hasta simples definiciones que hacen hincapié en los resultados del aprendizaje. La alfabetización visual es esencialmente la comprensión de los elementos visuales y la comunicación de su significado. A veces se confunde con la educación artística, pero no es el tipo de educación requerido para la interpretación de obras de arte. Es parte de una disciplina emergente conocida como comunicación visual. 


\section{- Análisis}

La cultura contemporánea se ha convertido cada vez en algo más dependiente de lo visual, sobre todo, por su capacidad de comunicación instantánea y universal. Un porcentaje muy alto de todo el aprendizaje sensorial es visual. La necesidad de aprender a leer imágenes visuales es urgente y afecta a todos los niveles de nuestra sociedad. Los niveles de alfabetización visual determinan directamente nuestro nivel de comprensión visual y la capacidad del individuo para poder leer las imágenes de una manera significativa. Las imágenes existen a nuestro alrededor, nos rodean. Entender las imágenes es una necesidad vital y enriquecedora de nuestra vida. No entenderlas constituye un analfabetismo visual.

Ausburn y Ausburn (1978: 287) sostienen que vivimos en la era de la cultura visual, lo que influye en nuestras actitudes, creencias, valores y estilo de vida. Las imágenes inundan nuestro entorno, ya sea en el ámbito privado o en el público, en una variedad de formas diferentes y a través de varios canales de comunicación. La alfabetización visual permite que una persona sea capaz de discriminar e interpretar las acciones visuales, los objetos y los símbolos que se encuentran en el mundo. La alfabetización visual estimula la apreciación y la comprensión de la comunicación visual. La falta de concienciación en torno a la alfabetización visual afecta a la habilidad de ser capaz de comunicarse de una manera efectiva. Al comprender los principios básicos de la alfabetización visual, las personas pueden producir imágenes que les faciliten comunicarse de una manera más eficiente.

Sin embargo, los textos visuales no son textos sencillos. La lectura y la escritura de textos visuales no es una simple fase transitoria que posteriormente se descarta a favor de la lectura y la escritura de palabras, los elementos visuales del texto no pueden ser muy complejos ya que se usan de modo amplio en todos los niveles de aprendizaje a través de los manuales universitarios y en múltiples artículos que reflejan investigaciones de postgrado. Los textos visuales no son por lo tanto una "opción académica fácil" ante los textos verbales (exclusivamente palabras), ya que su producción puede ser igualmente exigente. Tampoco se les debe considerar como una alternativa ante los textos verbales, sino que ambos son opciones complementarias, como lo demuestra la combinación del uno y el otro en muchos libros de referencia y en libros de texto en todos los niveles. Debido a que un diagrama puede proporcionar muchos niveles de información y ya que un gráfico estadístico a menudo puede ser mal interpretado, es necesario proporcionar un tipo de enseñanza explícita sobre lo que esos textos producen y lo que no quieren significar y cómo esos textos aportan un sentido concreto. 


\section{- Implicaciones prácticas}

Necesitamos la alfabetización visual a fin de salir adelante en nuestra vida cotidiana. Los contextos en los que se encuentran los textos visuales incluyen el encontrar nuestro camino, el seguir las instrucciones, el rellenar formularios del gobierno, las aplicaciones para el trabajo, la elección de bienes de consumo, la planificación de unas vacaciones, y así sucesivamente. Los textos visuales asociados a estas tareas incluyen mapas, callejeros, señales de tráfico y anuncios de las tiendas, las pantallas de vídeo, los mapas del tiempo, los impresos, la publicidad, los catálogos de los minoristas, las etiquetas de los productos, los folletos de viajes, los horarios de avión, etc. Todas estas formas combinan la información verbal y visual para aportar un sentido, se organizan junto con determinados principios del diseño gráfico que pueden ser enseñados y aprendidos de manera explícita.

Estamos firmemente convencidos de que los educadores y los profesores necesitan ampliar sus conocimientos y experiencia en el área de la alfabetización visual y que eso se debe hacer en relación con las prácticas culturales de las personas. Rodeados por los materiales visuales y por el aumento de su predominio sobre la palabra escrita para dar sentido al mundo, los educadores y los profesores tienen que ir más allá de la suposición de que lo "visual" es una representación "natural" y aprender a desarrollar habilidades críticas en la alfabetización visual, en particular, para obtener información sobre la diversidad cultural local y las presiones globales que se están produciendo a través de las imágenes. También creemos que los materiales visuales hacen más atractivo el aprendizaje y pueden fortalecer los vínculos entre la escuela y la vida fuera de la escuela mediante la vinculación de la cultura visual de las personas con los materiales escolares. Ayudan a introducir una metodología innovadora; esto es, estrategias de enseñanza y aprendizaje, es decir, el aprendizaje integrado de lengua y de contenidos, por el que se puede auspiciar una sensibilización hacia la cultura y los idiomas a través de materiales visuales, así como para producir materiales multinacionales y multilingües.

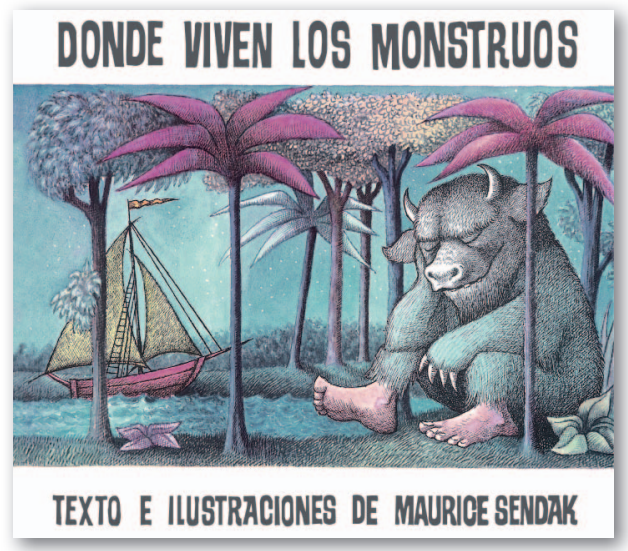

Ejemplo de álbum ilustrado.

Autor: Sendak, Maurice.

Editorial: Alfaguara.

Su completa comprensión requiere

de la alfabetización visual.

\section{BIBLIOGRAFÍA}

Ausburn, Ly Ausburn, F. (1978); Elkins, J. (2010); Kress, G. y Van Leuwen, T. (1996); Nikolajeva, M. y Scott, C. (200I); Nodelman, P (rg88Riddle, J. (2009); Sipe,L. y Driggs, C. (2007). 


\section{Bibliotecas escolares}

[Recursos de enseñanza / fondos documentales]

\section{- Definición, antecedentes y actualidad del término}

La biblioteca escolar es un servicio de información para todos los miembros de una comunidad educativa, que forma parte de los espacios y los procesos pedagógicos que tienen lugar en los centros escolares.

Las bibliotecas escolares son centros de recursos para las actividades de enseñanzaaprendizaje, están constituidas por un conjunto sistematizado y dinámico de servicios y fondos documentales que permiten:

- Desarrollar el hábito lector y el gusto por la lectura;

- buscar, localizar, acceder y valorar las fuentes de información para facilitar la solución de problemas y el desarrollo de los procesos autónomos de aprendizaje que hacen posible la formación permanente a lo largo de toda la vida;

- conocer diferentes soportes documentales, sus formatos y estructura, así como las herramientas para acceder a ellos y;

- desarrollar y apoyar las competencias básicas de las distintas áreas y materias curriculares y, de forma específica, las competencias comunicativas.

En el año 200o, las organizaciones internacionales IFLA (International Federation of Library Associations and Institutions) y UNESCO (Organización de las Naciones Unidas para la Educación, la Ciencia y la Cultura) difundieron conjuntamente el Manifiesto sobre la Biblioteca Escolar. Se trata de un documento propositivo, traducido a diferentes lenguas, que declara de forma explícita que las bibliotecas escolares son parte integrante del proceso educativo, pues proporcionan a los estudiantes información e ideas para desenvolverse con éxito en la sociedad; competencias para el aprendizaje a lo largo de toda la vida y también contribuyen a desarrollar la imaginación y la ciudadanía responsable.

Entre las funciones que desarrolla la biblioteca escolar, IFLA y UNESCO enumeran las siguientes:

a) respaldar y realizar los objetivos del proyecto educativo del centro escolar y del plan de estudios;

b) inculcar y fomentar en los estudiantes el hábito y el placer de la lectura, el aprendizaje y la utilización de las bibliotecas a lo largo de toda su vida;

c) ofrecer oportunidades para realizar experiencias de creación y utilización de información a fin de adquirir conocimientos, comprender, desarrollar la imaginación y entretenerse;

d) prestar apoyo a todos los estudiantes para la adquisición y aplicación de ca- 
pacidades que permitan evaluar y utilizar la información, independientemente de su soporte, formato o medio de difusión, teniendo en cuenta la sensibilidad a las formas de comunicación que existan en la comunidad;

e) facilitar el acceso a los recursos y posibilidades locales, regionales, nacionales y mundiales para que los estudiantes tengan contacto con ideas, experiencias y opiniones varias;

f) organizar actividades que estimulen la concienciación y la sensibilización en el plano cultural y social;

g) trabajar con el alumnado, el profesorado, la administración y las familias para realizar el proyecto educativo del centro escolar; proclamar la idea de que la libertad intelectual y el acceso a la información son fundamentales para ejercer la ciudadanía y participar en una democracia con eficiencia y responsabilidad; y

h) fomentar la lectura y promover los recursos y servicios de la biblioteca escolar dentro y fuera del conjunto de la comunidad escolar.

Para cumplir estas tareas, la biblioteca escolar -según IFLA y UNESCO- ha de formular políticas y crear servicios, seleccionar y adquirir materiales, facilitar el acceso material e intelectual a las fuentes de información adecuadas, proporcionar recursos didácticos y emplear a personal capacitado.

Este Manifiesto alcanzó una gran repercusión y ha impulsado desde entonces el quehacer de numerosos educadores y bibliotecarios que desarrollan un modelo activo de biblioteca escolar entendida como mediadora del conocimiento y como promotora de los procesos de aprendizaje de los estudiantes, futuros ciudadanos y ciudadanas, sin distinción de origen social, económico o cultural.

Con el propósito de ayudar a las escuelas en el proceso de implementar los principios del Manifiesto, se redactaron las Directrices de la IFLA/UNESCO para la biblioteca escolar en el año 20O2. Este documento presenta un modelo para promover la biblioteca escolar en los centros y aborda aspectos tales como la misión de la biblioteca, recursos (financiación, ubicación y espacio, equipamiento, colección...), funciones, habilidades y responsabilidades del personal bibliotecario, posibles actividades y cooperaciones, formación de usuarios, algunos programas para el desarrollo de la biblioteca y la instrucción en destrezas para el estudio y la competencia informativa, etc. 


\section{- Análisis}

En el contexto de la Sociedad de la Información y del Conocimiento resulta imprescindible que las instituciones educativas reflexionen y redefinan sus funciones. Los saberes tradicionales se tornan caducos y perecederos. Se multiplican los soportes, se diversifican los canales de difusión de la información y se extiende la idea de que no es necesario acumular muchos conocimientos, sino saber dónde están y cómo aprenderlos y/o desaprenderlos en el momento necesario. La biblioteca escolar es un buen aliado para alcanzar estos propósitos (Agustín, 2OII).

El modelo de biblioteca escolar ha estado estrechamente relacionado con el tipo de sistema educativo del que forma parte, y sus patrones de desarrollo han sido análogos a las respuestas que el propio sistema ha propuesto en cada uno de los países.

Históricamente, el eje de la escuela ha girado en torno a la enseñanza de los contenidos curriculares impartidos por el profesorado. Esta escuela demandaba una biblioteca concebida con funciones auxiliares, que se centraba en los soportes librarios, el procesamiento técnico de la colección y la conservación de los fondos, y estaba orientada -casi en exclusiva- hacia la custodia y, en su caso, hacia la lectura de textos literarios.

Las reformas educativas iniciadas en las últimas décadas del siglo XX establecieron como principios básicos la enseñanza comprensiva y el aprendizaje significativo, desplazando el centro de interés desde el profesorado hacia los estudiantes, que dejaron de desempeñar el rol de receptores pasivos para convertirse en los verdaderos protagonistas de los procesos pedagógicos.

Este cambio de modelo educativo ha supuesto una profunda revisión del concepto de biblioteca escolar, que ha comenzado a ser considerada como un centro activo de recursos informativos y documentales al servicio del aprendizaje, con una fuerte implicación estratégica en los procesos pedagógicos desarrollados en el centro.

Sin embargo, diversas circunstancias -cambios legislativos, recortes presupuestarios, etc.- han dificultado notablemente la consolidación y la sostenibilidad de este nuevo modelo de biblioteca.

En la actualidad, la biblioteca escolar experimenta las mismas tendencias que cualquier otro tipo de institución bibliotecaria: el carácter cada vez más audiovisual y multimedia de las colecciones bibliográficas; los cambios originados por las TIC y los entornos digitales o la integración y la cooperación en redes de sistemas bibliotecarios cada vez más amplios, entre otras. 


\section{- Implicaciones prácticas}

Dentro del programa de intervención educativa planteado por la biblioteca escolar, cobra especial importancia el desarrollo de un Plan lector.

Este Plan es un conjunto de estrategias - planificadas y coordinadas por profesionalespara promover el hábito de la lectura en el aula, el centro, la familia y el entorno social.

Es también un instrumento que parte de un análisis previo de las necesidades y de la detección de las principales carencias y dificultades relacionadas con la competencia lectora. Debe incluir principios generales que impulsen y dinamicen los cambios necesarios en la planificación didáctica de cada área o materia curricular, así como actuaciones globales que involucren a ciclos, etapas educativas o, en su caso, a todo el centro.

Por otra parte, un aspecto que suscita debate es el perfil profesional del responsable de la biblioteca escolar planteándose la discusión en torno a la idoneidad de la figura de maestro bibliotecario frente a la de bibliotecario escolar (Becerra, 20I2).

\section{Gráfico}

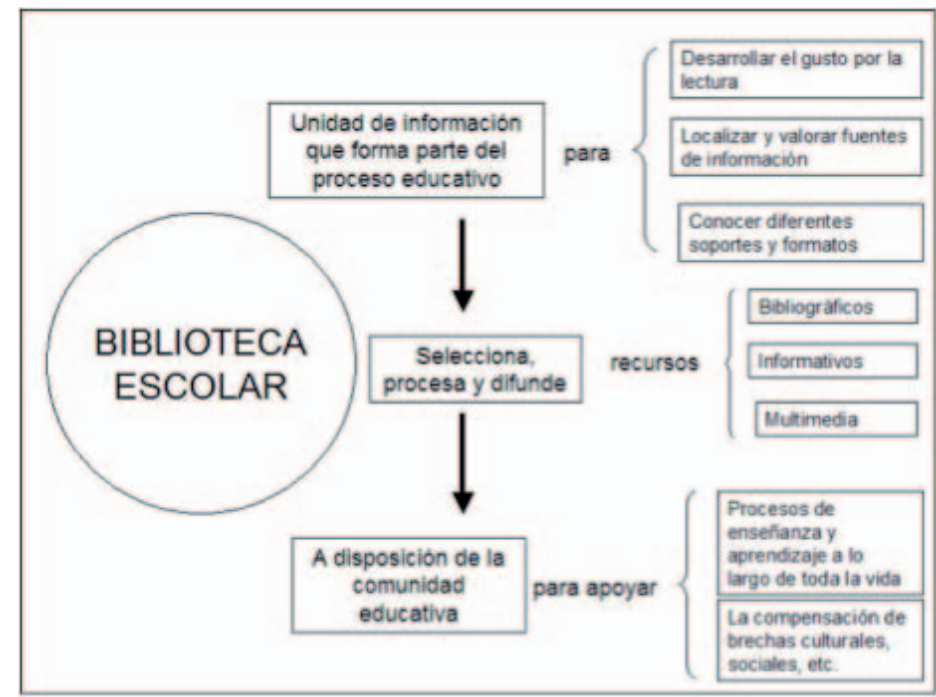

Fuente: Elaboración propia

\section{BIBLIOGRAFÍA}

Agustín Lacruz, M. C. (2OII); Becerra Martínez, D. (2OI2); Bibliotecas escolares [CD-ROM] (2008); Cuevas Cervero, A. (2007); Grupo Bibliomedia de la FMRPC (Federació de Moviments de Renovació Pedagògica de Catalunya). (2009a) y (2009b); Fuentes Romero, J. J. (2006); IFLA (International Federation of Library Associations and Institutions) (2002); UNESCO (Organización de las Naciones Unidas para la Educación, la Ciencia y la Cultura) (2000); López Gómez, P. y J. C. Santos Paz (eds.). (2009); Padorno, S. (2009); Pascual Díez, J. (2008); Valle Cuozzo, G. del; M.C. Ladrón de Guevara y M. B. Verde. (2007). 


\section{Clásicos- autores, textos}

[Canon / tradición]

\section{- Definición, antecedentes y actualidad del término}

Derivado del latín classicus, este adjetivo fue aplicado a la literatura por primera vez por Aulo Gelio, profesor de Retórica del siglo II d. C. Para diferenciar tipos de escritores, propone una distinción de base económica: scriptor classicus (el ciudadano de primera clase, el que pagaba más impuestos) y scriptor proletarius. Con este gesto, Gelio inaugura el carácter elitista que aún hoy se le reprocha al término (Fernández, 2008).

Es a partir del Humanismo que el concepto se asocia a la excelencia del arte de la Antigüedad grecolatina. Paralelamente, se desarrolla la idea de que el texto clásico es el que resiste el paso del tiempo, el texto que puede hablarle al hombre de todas las épocas. De allí su estrecha relación con la idea de "Canon” y de "Tradición”.

\section{- Análisis}

Al considerar el concepto dentro del sistema literario, es conveniente discriminar dos aspectos: lo que representa el clásico para los propios escritores del sistema y lo que representa para los lectores.

En lo que respecta a la escritura, desde algunas concepciones teóricas, el clásico aparece como el texto acabado, cerrado y modélico. Es, por ejemplo, la de Harold Bloom, quien al presentar a los veintiséis autores de su "canon occidental", los define como "autoridades en nuestra cultura” (Bloom, I996: II). Frente a esta concepción, la única lógica posible sería acatar el magisterio de estas "autoridades" de manera reverencial, lo que implica aceptar la "influencia" (Bloom, I976) que provoca en la posteridad y que aparece concebida como unidireccional.

Esta concepción del clásico es diferente si se considera desde el punto de vista de Jorge Luis Borges. Según el escritor argentino, los orígenes aparecen como "prefiguraciones" que van a ser resignificadas por los autores contemporáneos. Así "cada escritor crea a sus precursores" (Borges, I989: 89) desde su lectura y, más consciente y acabadamente aún, desde su reescritura. De este modo, el clásico, releído por la tradición, la fecunda y la vivifica. 
En lo que respecta a la lectura, uno de los autores que más y mejor trabajó esta línea fue Italo Calvino, en su célebre artículo "Por qué leer los clásicos" (I995), en el cual dio catorce respuestas al interrogante que plantea el título. A diferencia de la concepción de Bloom, que considera autores clásicos, para Calvino, los clásicos son los textos.

La tercera de sus respuestas se detiene en uno de los aspectos centrales del concepto, el modo de permanencia del clásico a través del tiempo: "Los clásicos son libros que ejercen una influencia particular ya sea cuando se imponen por inolvidables, ya sea cuando se esconden en los pliegues de la memoria mimetizándose con el inconsciente colectivo o individual" (Calvino, I995:I4). Este modo de permanencia lo convierte en insoslayable: "acosa" al lector ya sea desde la elección individual como desde la memoria cultural. Se "tropieza" con el clásico inevitablemente.

Si bien, para el propio Calvino, el clásico puede deslumbrar al que "se reserva la suerte de leerlos por primera vez” (I995: I4), es más usual que cargue con las lecturas anteriores, con las cosmovisiones desde las cuales fue interpretado. Esta es, precisamente, una de sus riquezas, la que le permite constituirse en vehículo de lecturas siempre vigentes. Esta permanencia en la cultura del clásico se explica, en parte, a partir de un concepto clave: el de "huella", que permite recuperar el legado, sostenerlo en el presente y plantearlo como camino para futuras producciones. "Los clásicos son esos libros que nos llegan trayendo impresa la huella de las lecturas que han precedido a la nuestra, y tras de sí la huella que ha dejado en la cultura o en las culturas que han atravesado" (I995: I5)”.

Las respuestas de Calvino apuntan a la elección subjetiva, al encuentro del lector con lo que llama "tu clásico". En el ámbito de la cultura, el clásico no aparece como el modelo cerrado, sino, por el contrario, como el texto capaz de interpelar al lector de todas las épocas, ya que "Un clásico es un libro que nunca termina de decir lo que tiene que decir" (I995:I5). 


\section{- Implicaciones prácticas}

Una de las discusiones que se plantea en el ámbito escolar respecto del clásico es su viabilidad. Problemas como la distancia lingüística, el esfuerzo de reponer el contexto, los prejuicios que lo preceden, suelen desalentar a los docentes a la hora de plantear su lectura.

Frente a esta situación se abren, básicamente, dos opciones: el abandono del clásico en el aula, con la pérdida de código cultural que esto implica para los estudiantes, o la búsqueda de estrategias para su abordaje. En esta última vertiente desarrollan su propuesta Martina López Casanova y María Elena Fonsalido (2005), como también Mar Campos (2005).

Las dos primeras proponen el abordaje desde su reescritura contemporánea, ya que el análisis del modo en el que funcionan la parodia, la alusión, o la cita pone en evidencia el procedimiento de construcción del clásico. Por su parte, Mar Campos plantea dos opciones: la primera, la lectura de textos literarios contemporáneos ambientados en momentos históricos de alta densidad, que ayuden a contextualizar el clásico (como por ejemplo, la trilogía Nuestros antepasados del propio Calvino); la segunda, la "utilización” del clásico que plantee problemáticas que lleguen hasta nuestros días (como por ejemplo, las diversas crónicas de la conquista de América).

\section{BIBLIOGRAFÍA}

Bloom, H. (199I) y (2009); Borges, J. L. (1989); Calvino, I. (199I); Campos, M. (2005); Fernández, C. (2008); López Casanova, M. y Fonsalido, M. E. (2005); Pozuelo Yvancos, J.M. y Aradra Sánchez, R.M. (2000) 


\section{Ciberliteratura}

[Literatura digital/ Hipertexto/ Escrilector]

\section{Definición, antecedentes y actualidad del término}

Término utilizado para hacer referencia a la creación literaria creada para un entorno virtual. Es equivalente a los términos electronic literature y digital literature, notablemente más utilizados en el mundo anglosajón. La literatura electrónica o ciberliteratura comprende un conjunto de manifestaciones que, con la finalidad estética propia de esta forma artística, constituyen una nueva manera de entender lo literario a partir de las posibilidades tecnológicas abiertas por el desarrollo del entorno digital. Una de sus características esenciales es la imposibilidad de acceso a las mismas fuera de dicho entorno por lo que no debe ser confundida con la literatura digitalizada, entendiendo por esta última la que resulta de la reproducción digital de textos ya existentes en formato papel o creaciones que, aunque no estén precedidas por su publicación en papel, responden a las mismas características de aquellas y pueden ser leídas como tales.

La ciberliteratura no puede ser reproducida de forma impresa pues se trata de textos "en movimiento" o dinámicos, que requieren generalmente en mayor o menor grado la interactividad del lector. A esta interactividad se une el entorno multimedia e hipertextual, característicos de dichas obras. Ciber es una expresión sincopada del inglés cybernetics (cibernética) y comprende, según el Diccionario de la RAE, lo perteneciente o relativo a la realidad virtual. Por su parte, el Ciberespacio se define como el ámbito artificial creado por medios informáticos.

\section{- Análisis}

El auge de las nuevas tecnologías y el uso generalizado de Internet ha proporcionado un nuevo espacio en el que constantemente se generan nuevos formatos que son utilizados por miles de usuarios con diversos fines. Nunca ajeno y siempre sensible a los cambios sociales, el ámbito de lo literario ha experimentado también las transformaciones generadas por esta nueva forma de comunicación. Internet se ha convertido en un espacio versátil para creadores, lectores y editores, en el que la literatura ha tomado derroteros diversos. Actualmente es posible encontrar en la red una extensa relación de revistas, foros literarios, editoriales, colecciones, páginas de y sobre autores, portales, proyectos de investigación literarios, bases de datos, recursos, bibliotecas virtuales, que dan debida cuenta del potencial de este medio para difundir, informar, recopilar, promocionar, 
publicitar o divulgar cualquier aspecto que tenga que ver con la literatura en sus distintas vertientes. En este contexto, tampoco la creación literaria ha permanecido al margen, dando lugar a la ciberliteratura, literatura digital o literatura electrónica cuya finalidad e intencionalidad es diferente a la de la literatura digitalizada, concepto este último con el que no debemos confundirla. La literatura digital -que no digitalizada- constituye en la actualidad un espacio creativo que ha generado nuevas formas de textualidad (Chico Rico, 2009) que implican un comportamiento específico de creadores y lectores, aunque no debemos obviar que, como ocurre con los fanfics, la blognovela o las redes sociales, el medio digital en general ya venía potenciando el que lectores y escritores explorasen nuevos posicionamientos que imprimen actualmente un carácter diferente a las relaciones tradicionalmente establecidas en la comunicación literaria. Pero de forma complementaria, la ciberliteratura va más allá y no sólo supone nuevos posicionamientos, sino que transforma profundamente la habitual relación lector-autor y la forma de concebir los procesos de escritura y lectura literarias (Morales Sánchez 2OII). Con respecto al primero de ellos, no podemos eludir el hecho de que los múltiples códigos utilizados en la creación dan como resultado una coautoría o autoría colectiva (programadores, diseñadores gráficos, escritores), dando lugar a un espacio de creación múltiple que puede llegar a contemplar la participación del lector en dicho proceso, circunstancia que origina asimismo la formulación del concepto de escrilector. En la misma línea el proceso de lectura también se ve influenciado por esta posibilidad de interactuación -aunque no se da en todas las obras en el mismo grado- a la que ha de sumarse la utilización por parte del lector de distintas estrategias lectoras para acceder al texto (Borrás, 20o8: 29). Por otra parte el resultado de este proceso creativo es un entramado textual complejo, que puede albergar distintos niveles e itinerarios combinando imagen, sonido, palabra con múltiples efectos. En este sentido, Espen Aarseth (2004: I2I) llamará la atención sobre el hecho de cómo el usuario "puede perderse y descubrir caminos secretos en los textos, no metafóricamente, sino mediante las estructuras topológicas de la maquinaria textual", en una nueva intertextualidad que ahora está explícita y visible a través de enlaces. Todo ello hace que uno de los rasgos más significativos de la ciberliteratura sea la ruptura de la linealidad tradicional utilizando la posibilidad que le ofrece su estructura hipertextual. Las estructuras textuales pueden adquirir formas diversas y plantear distintos grados de intervención -evitamos interacción porque ello implicaría una dinámica de emisión y recepción, no siendo exacto que siempre se de reciprocidad en el proceso-, incluso obras que combinan distintas de estas posibilidades en el mismo texto. Entre ellas podríamos destacar: obras con distintos itinerarios posibles, a veces planteados como un $n^{\circ}$ aparentemente infinito; rutas de lectura imposibles de repetir o itinerarios que no permiten el retroceso; textos que sólo son visualizables cuando el lector realiza acciones; textos que conjugan esto último con la estética de los videojuegos para plantear pruebas según niveles de dificultad; historias en las que podemos elegir personajes o escenarios; obras en las que el lector escribe y construye el texto; poemas en tres dimensiones realizados a partir de la selección de palabras...etc. 
Ahora bien, la naturaleza especial de estos textos y las múltiples posibilidades que albergan en cuanto a formatos hace difícil su clasificación. A la hibridación del código lingüístico habitual en la literatura tradicional con otros códigos de carácter audiovisual, se une la dificultad de identificar en estas creaciones los rasgos estructurales mediante los que habitualmente reconocemos la poesía, la narrativa o el teatro. Ello ha originado distintas propuestas para su clasificación. Básicamente, una primera taxonomía parte de la descripción de las distintas creaciones a partir de los rasgos esenciales mediante los que se identifican los géneros tradicionales: poesía electrónica/ciberpoesía, ciberteatro/ ciberdrama, narrativa digital o hipertextual; de manera particular, algunas propuestas teóricas como la formulada por Ma Dolores Romero -en el seno del grupo de estudio LEETHI(2OII) apuntan la posibilidad de plantear nuevas formas de clasificación que atienda a la especificidad de la literatura electrónica y su medio, con independencia de los rasgos que mantenga con la literatura en soporte tradicional. Como resultado, la ciberliteratura se dividiría en literatura hipertextual (el lector se deja llevar por el enlace) literatura ecfrástica (texto e imagen) y literatura serendipia (serendipity) que será aquella en la que el lector alcanza su propósito a través de un proceso casual o imprevisto. En este sentido puede afirmarse que el estudio de la tipología es uno de los ámbitos que ayudará a establecer las especificidades de la literatura electrónica, pues el análisis de los ejemplos concretos permitirá determinar sus principales rasgos estéticos.

\section{- Implicaciones prácticas}

Las obras de literatura electrónica no son todavía muy conocidas por el público en general debido, principalmente, a que constituyen una propuesta novedosa que no se inserta en circuitos editoriales ni académicos. Salvo excepciones la mayoría de las obras pertenecen al mundo anglosajón y su difusión ha sido muy limitada. De hecho, el interés que este tipo de propuestas ha despertado en los ámbitos teóricos universitarios no se corresponde ni con la difusión entre los lectores ni con su inclusión en la enseñanza de la literatura. Si bien es cierto que la proliferación de obras de los últimos años han ampliado la esfera de usuarios la lectura y el estudio de estas obras son más objeto de cursos específicos incluso de postgrados- o de temas aislados en los temarios de teoría de la literatura sobre la literatura y las nuevas tecnologías. Ello hace que la ciberliteratura no se emplee todavía al mismo nivel que las obras literarias tradicionales en otros ámbitos educativos. Este conocimiento, aún deficiente, es en la actualidad diametralmente opuesto a la creación de portales, blogs y webs específicas sobre la materia. A continuación se ofrecen algunas de las direcciones que contribuyen en la actualidad a la difusión de ciberliteratura y a su conocimiento en el ámbito hispánico:

Bliblumliteraria. Blog específico de literatura digital editado por Félix Remírez que ofrece información sobre todo lo que ocurre en el mundo digital además de albergar el acceso 
a su creación propia. Es uno de los autores en lengua no inglesa que ofrece obras de una gran calidad tanto por su estética como por su originalidad. http://biblumliteraria.blogspot.com.es/

Domenico Chiappe, portal del autor http://www.domenicochiappe.com/pg_d__.html

Electronic Literature Association . Asociación de referencia de escritores y académicos vinculados creativa o teóricamente al mundo de la ciberliteratura, en cuya página www. eliterature.org pueden encontrarse dos volúmenes de la Antología especializada de obras digitales.

Hermeneia. Portal coordinado desde la Universidad de Barcelona por Laura Borrás e integrado por especialistas de ciberliteratura tanto creadores como teóricos. En él se reúne toda la información sobre los más recientes estudios y eventos relacionados con la ciberliteratura en el marco internacional.

http://www.hermeneia.net

Laboratoire Paragraphe. Université Paris 8. Portal del grupo multicisplinar ubicado en la Universidad de París centrado en el estudio de la epistemología hipertextual desde $\mathbf{9 9 5 .}$ http://paragraphe.info/content/view/I8/66/lang,fr/

Literaturas españolas y europeas del texto al hipertexto. Leethi. Grupo interdisciplinar de la Universidad Complutense de Madrid que reúne a investigadores de diversa procedencia y abarca el estudio de la literatura digital desde distintas perspectivas. http:// www.ucm.es/info/leethi/

Jaime Alejandro Rodríguez. Página personal. Universidad Javeriana de Bogotá, a través de la misma puede accederse a sus proyectos, cursos y obra sobre y de literatura digital. http://www.javeriana.edu.co/Facultades/C_Sociales/jaime_a/

Portal del Observatorio para la Cibersociedad. Espacio para la reflexión, el análisis y el debate sobre el ciberespacio desde las ciencias humanas y sociales. Recoge en su espacio las intervenciones y ponencias presentadas en los distintos congresos de la Cibersocidad realizados hasta el momento con importantes aportaciones en el ámbito de estudio de la ciberliteratura.

http://www.cibersociedad.net/

Portal de Literatura Electrónica Hispánica, coordinado por Juan José Díez. Parte del proyecto de la Biblioteca Virtual Cervantes, recoge las últimas novedades en creaciones y artículos sobre ciberliteratura.

http://bib.cervantesvirtual.com/portal/literaturaelectronica/ 
Rui Torres. Página personal. Universidade Fernando Pessoa http://telepoesis.net/ poesia.html

\section{Para aprender a crear ciberliteratura:}

\section{Taller de narrativa digital. Universidad Javeriana.}

http://www.javeriana.edu.co/relato_digital/r_digital/taller/taller_index.htm . Iniciativa única en su género, proporciona herramientas e información para el aprendizaje en la lectura y construcción de narraciones digitales. Consta de tutoría virtual, foro interactivo y ejercicios de diversas técnicas relacionadas con el diseño y construcción de hipermedias de ficción. Está coordinado por el colombiano Jaime Alejandro Rodríguez, uno de los autores pioneros de ciberliteratura y de reconocido prestigio internacional.

\section{Imágenes de obras digitales:}

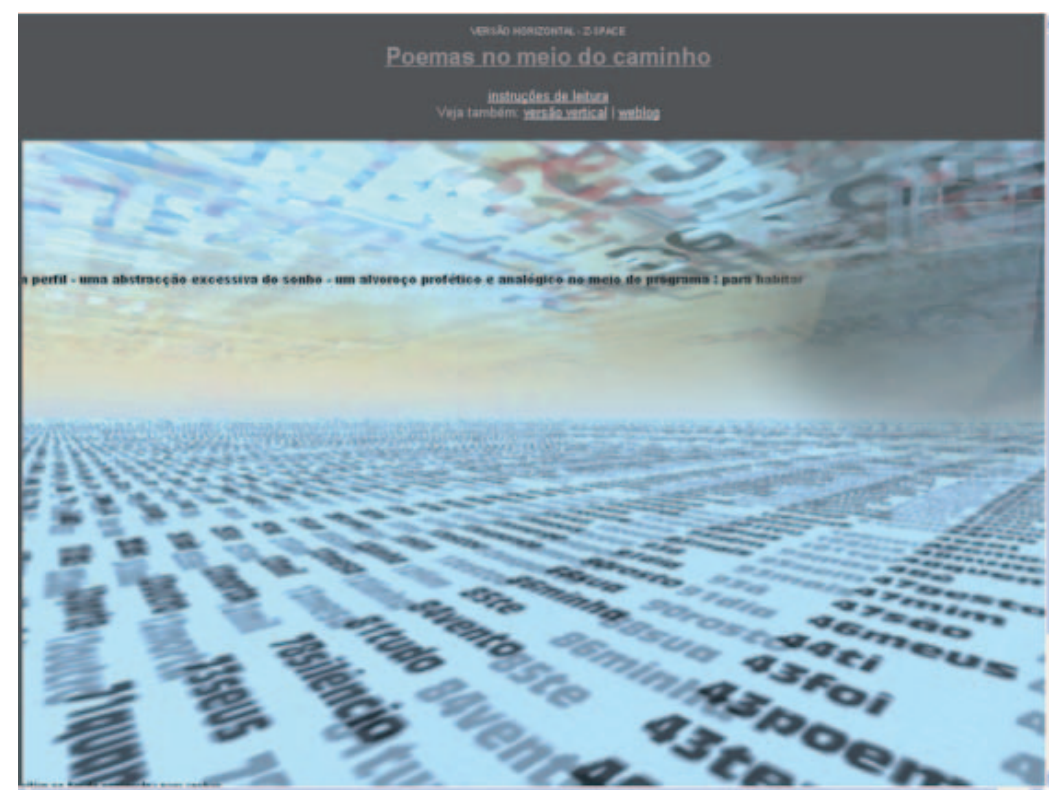

Poemas no meio do caminho. Rui Torres, 2008 


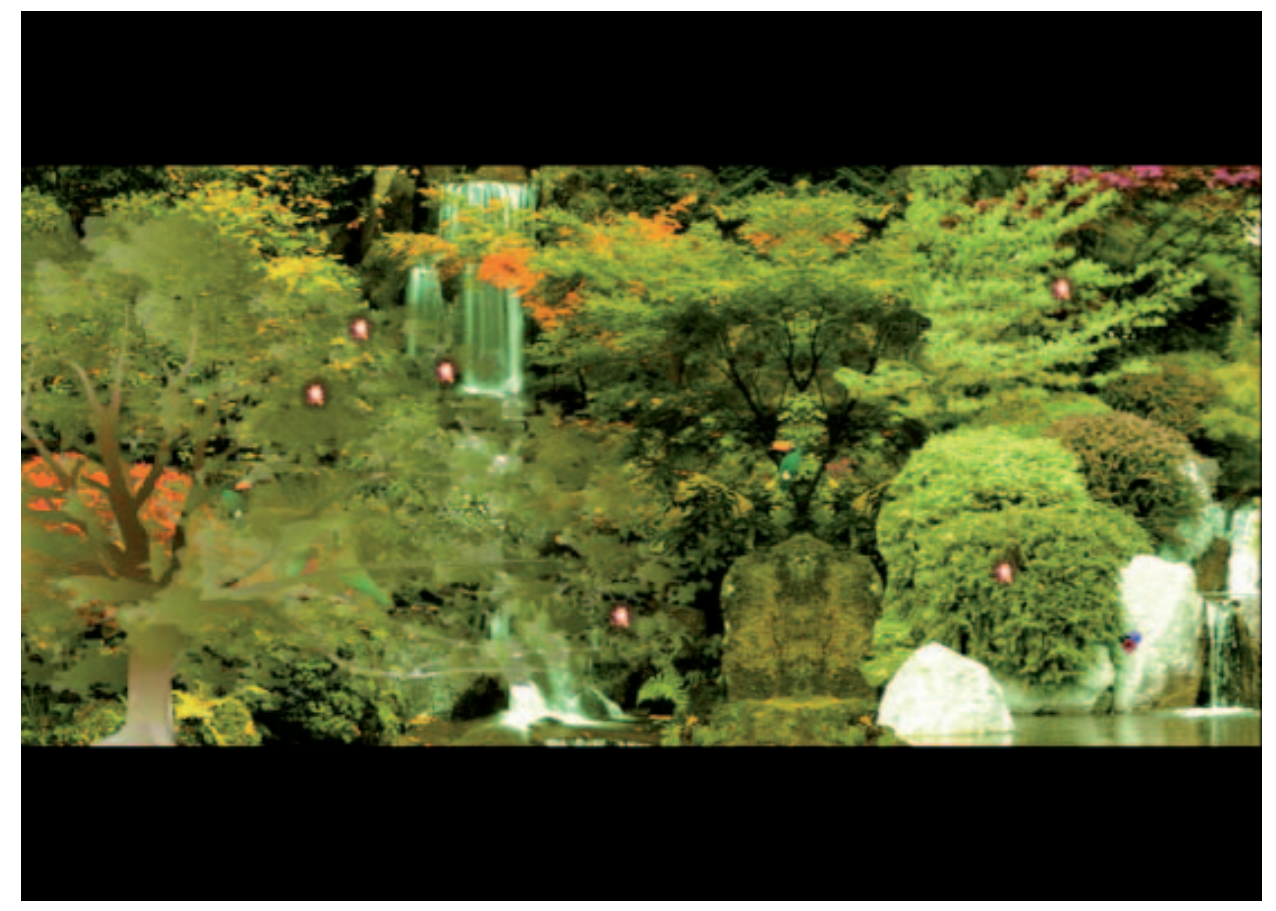

El jardín de los relatos inacabados. Félix Remírez (2009)

\section{BIBLIOGRAFÍA}

Aarseth, E. (2004); Albaladejo Mayordomo, T. (2009); Borrás, L. (2008); Chico Rico, F. (2009); Morales Sánchez, I. (2OII); Murray, J. M. (I999); Romero, Ma D. (2OI2); Sánchez Mesa, D. (ed.) (2004); Tortosa, V. (ed.) (2008).

\section{[I.M.S.]}




\section{Edición en la nube}

[Alojamiento web /cloudcomputing]

\section{- Definición, antecedentes y actualidad del término}

Es la traslación al español del término "Cloud Publishing”. El alojamiento web en la "nube" (cloudhosting) se basa en las tecnologías más innovadoras que permiten a un gran número de máquinas conectadas a un grupo de medios de almacenamiento actuar como un sistema.

La tendencia actual del entorno 2.0 se basa en que a mayoría de aplicaciones de información ya no están en un dispositivo concreto, sino que éste va a ser simplemente el medio de comunicación para acceder a la información. Las distintas aplicaciones permiten el acceso a los datos almacenados en un servidor de Internet, en este caso a una editorial (y es este servidor el que pertenece a la red que conforma la nube) y en consecuencia cada vez se almacena menos información en los dispositivos y se pasa más tiempo conectado a Internet.

Este modelo de alojamiento de datos es una de las iniciativas tecnológicas más importantes de la informática empresarial hoy en día y está provocando cambios en la manera en la que los negocios tienen acceso a los servicios a través de Internet, cambiando la velocidad y la agilidad de negocio sin aumentar los gastos. El cloudcomputing proporciona nuevas maneras de pensar la arquitectura de la información y los modelos de entrega. Con la estrategia de información en la nube, todo se convierte en un servicio para que las empresas desarrollen nuevas iniciativas sin una gran inversión inicial. La computación en nube ofrece nuevos modelos de negocio y puede ser útil para ayudar a cambiar la forma en que las empresas colaboran, operan y compiten.

\section{Análisis}

El libro electrónico está trayendo algunas propuestas de negocio innovadoras e imaginativas, de las cuales una de las más significativas se encuentra en la dinámica de lo que conocemos como cloudcomputing. De alguna manera el concepto de biblioteca personal en la nube proporciona una nueva alternativa y oportunidad para la promoción de la lectura en soporte digital ante a la resistencia al cambio que muestran algunos usuarios frente a la lectura en formato electrónico, ya que añaden múltiples funcionalidades nuevas a las posibilidades del formato impreso. Entre estas el almacenamiento del contenido digital en la nube potencia enormemente la capacidad para proporcionar servicios a los usuarios 
finales para descubrir, seleccionar y acceder a los libros que necesitan en un momento determinado desde cualquier dispositivo que tenga capacidad para leer un archivo digital normalizado. En España son varias las editoriales que desarrollan edición en la nube como 24symbols: el Spotyfy de los libros (http://www.24symbols.com/), Musa a las 9: Editorial digital en la nube (http:// www.musaalas9.com/index.php), Amphibia: El cloudreading (http://www.amphibiaeditorial.com/)

\section{- Implicaciones prácticas}

Una de las propiedades del formato digital es la independencia entre texto y contenido frente a la integridad subyacente de texto y soporte que caracterizaba al libro impreso. Esta característica proporciona al libro un carácter multiformato y multidispositivo que hace posible leer en cualquier momento, en cualquier lugar y desde cualquier dispositivo, en una formula " $24 / 7$ "; es decir un servicio accesible 24 horas siete días a la semana; lo que además permite sincronizar la lectura, pudiendo comenzar a leer en el ordenador del trabajo, continuar en "tiempos muertos", en el smartphone mientras se desplaza en trasporte público al domicilio y, posteriormente, hacerlo en un dispositivo dedicado conservando todos los elementos personales como notas, y puntos de lectura (Fundación Telefónica, 2OIO). La personalización de contenidos de los servicios cloud conlleva un valor añadido destacable, desde el almacenamiento en la nube, a la ventaja de la consistencia de contenidos sincronizada a través de múltiples dispositivos.

Por otra parte, el sistema de tecnologías cloud hace posible que un usuario tenga un importante número de libros en la nube, lo que hace necesario disponer de un sistema de búsqueday de acceso rápido. Siendo un paso necesario para el desarrollo de servicios en la nube. El almacenamiento en la nube proporciona un mayor nivel de eficacia para el descubrimiento de contenidos. Los servicios de búsquedasemántica en la nube deberían ser la herramienta apropiada para simplificar los procesos de búsqueda, incluyendo la búsqueda de anotaciones, y citas; añadiendo la capacidad de búsqueda desde diferentes dispositivos móviles, facilitando de este modo la eficacia de añadir y anotar nueva información, y acelerando los procesos de descubrimiento de contenidos, ypromoviendo la interactividad entre los datos y el contenido, especialmente en la literatura científica.

La nube proporciona a los lectores un marco no solo para la difusión y sincronización de la lectura desde distintos dispositivos móviles, sino que también ofrece una oportunidad para la recomendación y el descubrimiento de nuevos títulos de interés del lector. Las herramientas móviles de lectura basadas en filtros de contenido por medio de algoritmos sirven para descubrir nuevos libros; tales como libros relacionados con los gustos lectores o nuevos libros de áreas de interés del usuario. La retroalimentación del servicio de recomendaciones colaborativas se apoya en la recogida y análisis de un amplio conjunto 
de información de conductas, actividades y preferencias de otros usuarios basadas en la similaridad de los gustos.

La edición en la nube junto con el desarrollo de tecnologías móviles con mayor capacidad de usabilidad están proporcionando un elenco de servicios de valor añadido que están siendo determinantes en el incremento y transformación de la industria editorial en una deriva hacia lo digital. Aunque estos modelos de desarrollo que facilitan la disponibilidad, acceso y ubicuidad de la inofrmación se encuentran en una tierra de nadie respecto a los derechos fundamentales como el de la privacidad y seguridad de los datos a los que habrá que estar muy atentos para que estos no se vean conculcados

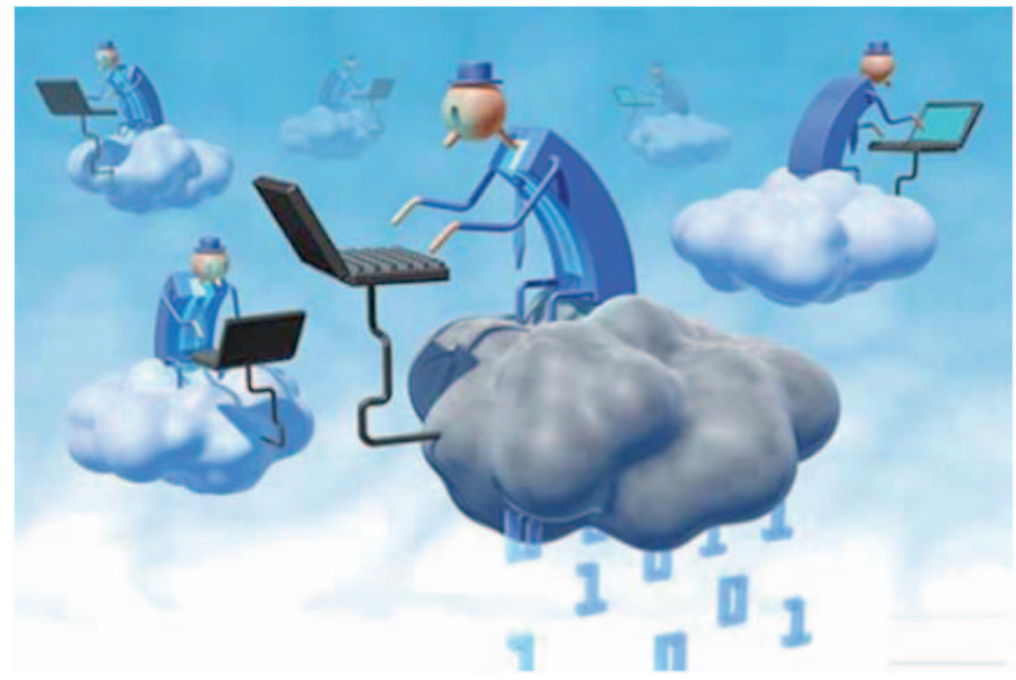

\section{BIBLIOGRAFÍA}

Cordón García, J.A.; Gómez Díaz, R.; Alonso Arévalo, J. (2OII); Cordón García, J.A. (2OII).

[J.A.C.G.] y [R.G.D.] 


\section{Estratégias de leitura}

[Leitor estratégico; Reading Strategies; Estrategias de Lectura]

\section{- Definição, Antecedentes e Atualidade do conceito}

A palavra estratégia vem do grego antigo stratègós (de stratos, "exército", e ago, "liderança" ou "comando" tendo significado inicialmente "a arte do comando, da liderança" e designava o comandante militar, à época de democracia ateniense. O idioma grego apresenta diversas variações, como strategicós, ou "próprio da liderança” (general); stratége$m a$, ou "estratagema, ardil de guerra"; dentre outras. Atualmente, o conceito de estratégia é muito utilizado, inclusive no âmbito da economia, antropologia, sociologia, ciências políticas, dentre outros; no entanto, também se encontra abundantemente na literatura educacional. À primeira vista parece tratar-se de um conceito estabilizado, de sentido consensual e único, de tal modo que, na maior parte das vezes, entende-se ser escusada a sua definição. Aqui falamos de estratégias de leitura, expressão criada por estudiosos da psicolingüística e da leitura, já na década de zo do século passado (Souza e Girotto, 2OIO) para designar, dialogando com seu princípio etimológico, uma abordagem de ensino que permitisse ao aprendiz apropriar-se de 'estratagemas' da prática leitora dirigidas à "arte" da compreensão. São aquelas cujas ações e operações trazem "liderança” identitária ao leitor, em face, propriamente, da constituição de seu estatuto leitor.

Não é sem razão a preocupação de pesquisadores da área, como a de Duffy(I986): em levar os alunos a realmente desenvolverem estratégias de leitura de forma independente e integrada requerendo orientações intencionalmente planejadas e refinadas que vão muito além de técnicas. O autor americano argumenta que as estratégias não são habilidades que podem ser ensinadas como exercícios de repetição; são planos que resultam na construção do significado. Ser estratégico é muito mais que saber as estratégias. Quando um estrategista se depara com um problema de estratégias, ele as coordena, substitui e agrupa de forma a solucionar o dado problema, em outras palavras, elas serão constantemente alteradas, ajustadas, modificadas, e testadas até que construam o significado e o problema seja resolvido.

\section{- Análise}

O processo de atribuir sentidos a um texto é chamado de compreensão. O que os alunos entendem quando lêem um texto depende de quatro condições: de seu conhecimento prévio e suas experiências, das características do texto que está lendo, do contexto da leitura, e das estratégias aplicadas à leitura. 
Tais estratégias vêm sendo consideradas como importantes instrumentos de auto-regulação do aluno, na medida em que contribuem para ajudá-lo a aprender e exercer mais controle sobre o seu próprio processo de aprendizagem do comportamento leitor (Pozo, I996; Da Silva \& Sá, ı997; McLaughlin \& Allen 2002)

Vários estudos (Duffy, I986; Pressley \& Wharton-McDonald, I997) mostram que o trabalho pedagógico com as estratégias cognitivas e metacognitivas criam situações de aprendizagem propícias aos alunos, cujos resultados implicam na melhoria considerável no processamento da leitura, contribuindo na formação de leitores autônomos. Desse ponto de vista, o trabalho com as estratégias de leitura que envolve levantar questões antes, durante e depois da leitura; tomar alguma providência quando se percebe que não entendeu o texto ou parte dele; realizar autoquestionamento para investigar se houve compreensão; estabelecer metas e acompanhar o progresso em direção à elas; modificar as estratégias utilizadas, se necessário; bem como prever acontecimentos; clarear sentidos ambíguos; resumir trechos do texto lido; checar informações; dentre outras dimensões da competência leitora em desenvolvimento, cria um modelo mental que tem um impacto positivo na compreensão leitora.

\section{- Implicações práticas}

Em sala de aula, ao proporcionar uma capacidade de reflexão, mediante as estratégias metacognitivas, o professor organiza condições didático-pedagógicas, que levam os alunos, por exemplo, a caracterizar o tipo de compreensão a que correspondem às perguntas de um texto, o que significa levá-los a refletir sobre as operações mentais a serem realizadas, a avaliar se as respostas às suas perguntas estão no texto, ou se é preciso pensar e deduzir com base nos indícios do texto e em seu conhecimento de mundo.

Por isso, o monitoramento do próprio processo de aprender a ler lendo de forma estratégica, em um processo de letramento ativo, é essencial ao sucesso dos alunos. Os estudantes bem sucedidos em leitura são os que apresentam a capacidade de monitoramento bem desenvolvida, sendo capazes de monitorar a compreensão, o uso de estratégias, o investimento de esforço e o engajamento nas tarefas, dentre outras atividades. As estratégias de monitoramento da compreensão leitora implicam, desse ponto de vista, que o indivíduo tenha tomado a consciência realista do quanto está sendo capaz de ler atribuindo sentidos às informações presentes nos textos, quer sejam os fictícios ou os científicos.

Nestes termos, a demonstração de estratégias de compreensão a partir da exemplificação de processos cognitivos (da visualização, da inferência, das conexões, da sumarização, dentre outras) por parte do professor e colegas de um círculo de leitura da turma, por exemplo, contribui de forma inequívoca para melhorar a compreensão na leitura do leitor mirim (Harvey e Goudvis, 2000). Vale esclarecer que didaticamente as estratégias podem ser trabalhadas uma a uma, em unidades de ensino, todavia o leitor mirim em for- 
mação deve ter clareza que todas são mobilizadas, quase que simultaneamente no processamento da leitura.

Somente em um ambiente que proporciona um envolvimento ativo com a leitura, que leve os alunos a ler muito, a ouvir o ler, a formular questões e a discutir possíveis respostas, é que o professor pode se constituir como mediador de leitura, permitindo aos alunos refletir sobre o significado de material escrito de forma estratégica e reflexiva e a compreender melhor o que lêem.

\section{Gráfico}
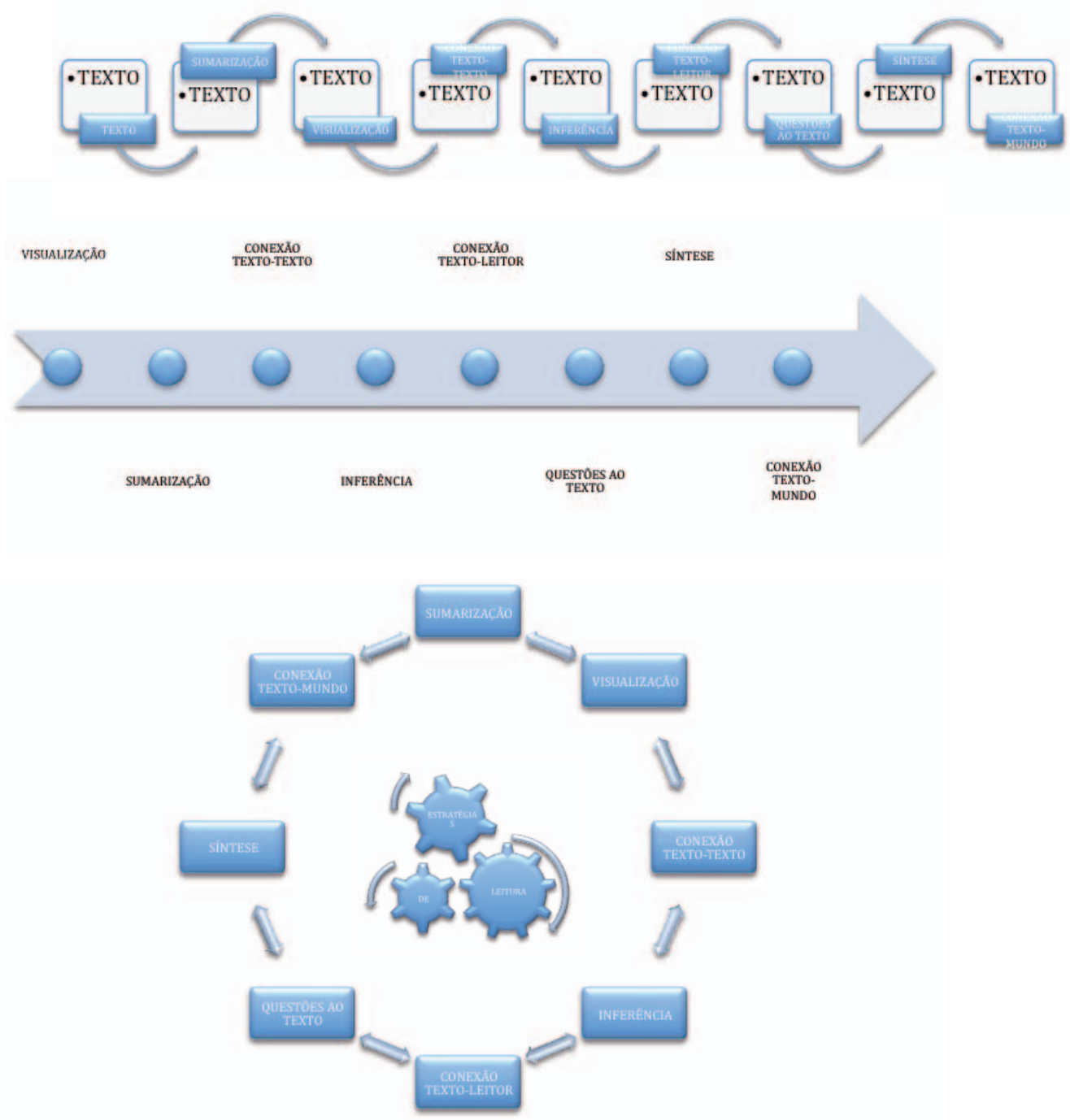

\section{REFERENNCIAS}

Da Silva A. L. \& Sá, L. (I997); Duffy, G. G.(I986); Harvey, S., \& Goudvis, A. (200o); McLaughlin, M., \& Allen, M. B. (2002); Pozo, J. I. (I996); Pressley, M., \& Wharton-McDonald, R. (I997); Girotto C. \&, Souza, R. (2OIO).

Site consultado:

http://origemdapalavra.com.br/palavras/pergunta/. Consulta em: 2O/O4/2OI2. 


\section{Fonología y Fonética}

[Linguística/ pronunciación/ fonética computacional]

\section{- Definición, antecedentes y actualidad del término}

La Fonología y la Fonética son las disciplinas lingüísticas que corresponden al nivel fónico de la lengua, es decir, el plano de la expresión del signo lingüístico, el significante. En el plano fónico se atiende al sonido como objeto de análisis. La Fonología se encarga del estudio del fonema, es decir, la unidad más pequeña en que puede descomponerse un grupo fónico; por ejemplo, la palabra casa consta de cuatro fonemas: /k/+/á/+ /s/ + /a/. En cambio, la Fonética es la disciplina que se ocupa del estudio de los sonidos, de describir las diferentes maneras de pronunciar los fonemas; por ejemplo, en la palabra casa podemos percibir con claridad cómo en un grupo formado por varios hablantes cada uno de ellos pronuncia el fonema /s/ de manera distinta, con matices diferentes que, aunque preservando los rasgos distintivos del fonema, se ejecutan de formas diversas.

Los fonemas están formados por una serie de rasgos diferenciadores (rasgos distintivos) que permiten que se distingan entre sí. Los fonemas son unidades no significativas pero que permiten diferencias significados, por eso se consideran unidades mínimas de la lengua diferenciadoras de significados. Por ejemplo, en la palabra casa, el fonema $/ \mathrm{k} / \mathrm{se}$ opone a /p/ y se diferencia de él puesto que provoca cambios de significado de la palabra: casa frente a pasa.

\section{- Análisis}

Los sonidos que cada individuo puede producir son muy variados pero las lenguas particulares seleccionan un número limitado de "sonidos ideales" o fonemas que en el caso del español son veinticuatro (cinco vocales y rg consonantes). No obstante, esos “sonidos ideales" son pronunciados de distintas maneras por los diferentes hablantes; esas formas de pronunciar un fonema son los "sonidos reales" individuales, las variantes concretas de los fonemas. Los sonidos, por tanto, son ilimitados en número. Así pues, los fonemas son unidades abstractas, intencionales, modelos del plano de la lengua: en cambio, los sonidos son las representaciones concretas de los fonemas que se perciben por el oído, son los elementos físicos propiamente dichos que forman parte del plano del habla.

El significante del signo lingüístico se puede estudiar en el plano de la lengua, esto es, como modelo de sistema de reglas que organiza el aspecto fónico, la Fonología; y en el plano del habla, como articulación de los órganos fonadores del ser humano que producen determinados sonidos y que son estudiados por la Fonética. 
El acercamiento a la Fonética puede hacerse desde el plano articulatorio, encargado de analizar las operaciones que realizan los órganos fonadores -las cuerdas vocales, la lengua, los alvéolos, el paladar, el velo del paladar, los dientes, los labios y la cavidad nasalpara la realización y emisión de los sonidos; o desde el plano acústico, que estudia el sonido no desde su producción sino desde su percepción, la onda sonora. Tanto la fonética articulatoria como la acústica están activas en el proceso de comunicación humano.

\section{- Implicaciones prácticas}

En el ámbito docente, la didáctica de las disciplinas fónicas nos permitirá ofrecer modelos de pronunciación de distinta naturaleza (estándar, dialectales, cultos, etc.). Los ámbitos principales de aplicación de la fonética son: la enseñanza de la pronunciación (dentro del ámbito de la didáctica de la lengua ya sea materna o extranjera, aunque haciendo uso de procedimientos y estrategias didácticas diferentes); la fonética clínica (que diagnostica y trata las patologías de la voz y el habla); la fonética computacional (que permite la síntesis de la voz y el reconocimiento automático del habla para aplicaciones de diferente naturaleza), y la fonética forense (que se emplea para el peritaje judicial y la identificación de la voz para fines forenses, jurídicos, policiales, etc.).

La enseñanza de la pronunciación promueve el desarrollo de estrategias que permiten emitir y entender los discursos orales. Por su importancia en el acto comunicativo, debe formar parte del diseño curricular de los alumnos de Educación Infantil, Primaria y Secundaria; y han de incorporarse a las actividades de clase al igual que se hace con las demás destrezas lingüísticas. En el ámbito de la enseñanza del lenguas extranjeras o segundas lenguas, la didáctica de la fonética y de la pronunciación de la lengua meta tienen que formar parte de los currículos desde los niveles iniciales. La corrección fonética se ejecutará para intervenir en individuos que posean problemas de pronunciación de determinados fonemas.

\section{BIBLIOGRAFÍA}

Alarcos Llorach, E. (1986 [1959]); Alcoba, S. (Coord.) (2000); Anderson, S. R. (1990); Cortés Moreno, M. (2002); Gil Fernández, J. (I988); Gil Fernández, J. (Ed.) (2000); Gil, J. y Llisterri, J. (2004); Hidalgo Navarro, A. y Quilis Merín, M. (2004 [2002]); Iribarren, M. C. (2005); Martínez Celdrán, E. (I996); Poch Olivé, D. (r999); Quilis, A. (I999 [ı993]); Quilis, A. (200o [1997]). 


\section{Gestión Cultural}

[Animación sociocultural/ educación social/ pedagogía]

\section{- Definición, antecedentes y actualidad del término}

La animación sociocultural es un conjunto de prácticas, métodos y técnicas con intencionalidad educativa, contenido cultural y continente social, con la pretensión de mejorar la calidad de vida de un colectivo o comunidad de personas. Un objetivo que se concreta en favorecer el acceso a una vida más activa y creadora, mejorar la autonomía personal y grupal, aumentar la interactividad comunitaria o potenciar la capacidad transformadora del entorno.

Aparece por vez primera citado en una iniciativa de la UNESCO en Austria (I95O) y fue en Francia donde se ha desarrollado más como profesión. Aunque existen algunas experiencias pioneras que beben de su filosofía en nuestro país (Ateneos obreros, Misiones Pedagógicas, Universidades Populares, etc.), es con la llegada de los ayuntamientos democráticos cuando se populariza, quizás en demasía y con decepcionantes resultados, su aplicación práctica.

Tal vez su acepción más aceptada sea la de una metodología de acción socioeducativa que, partiendo del protagonismo grupal, busca el desarrollo comunitario. En todo caso, son frecuentes las referencias a su polisemia y a la variedad de términos afines que la adjetivan. Hoy en día, ante los fracasos de las políticas culturales institucionales sobre todo, se detecta una clara voluntad de recuperar y actualizar dicho concepto.

El término Gestión Cultural obedece a una concepción más operativa y profesional de la cultura. Se pretende alcanzar los objetivos con unos indicadores de eficacia y eficiencia muy en la línea de la visión economicista o extra cultural de la cultura en detrimento del aspecto relacional de la misma. En España, su uso y profesionalización se generaliza a partir de los años ochenta.

\section{Análisis}

Ambos términos non son sinónimos. Sen embargo, Animación y Gestión Cultural pueden y deben ser complementarias formas de proceder en la acción educativa y cultural con la ciudadanía y los colectivos que la representan. Para un territorio dado, se recomienda diseñar e implementar una única política cultural consensuada con la diversidad de agentes con incidencia en el, fortalecida con una complementaria diversidad de estrategias que beban de sendos conceptos.

La cultura sirve de dispositivo generador y constructor de la comunidad. Cualquier política cultural persigue tanto objetivos sociales y educativos, como políticos -legitimación, 
rentabilidad electoral...-, o económicos. Enfatizar los dos últimos es aceptable siempre que no se pierdan de vista los primeros.

\section{- Implicaciones prácticas}

La Animación Sociocultural se demuestra más eficaz a escala microsocial y en un contexto socio-comunitario específico. De esta forma, su praxis se produce en una comunidad delimitada. Tiene como objeto el implicar preferentemente a sus miembros o grupos organizados en proyectos educativos, sociales y culturales (como ejemplos: en el fomento de actitudes y comportamientos que incentiven la interrelación y la participación social; la promoción de la creatividad y la capacidad expresiva; la consecución de la autorrealización individual y la transformación social, etc.), de ahí que el marco de acción local parezca el más pertinente para la puesta en práctica de sus preceptos y métodos. En la actualidad, como modelo de acción-intervención, se aplica a distintos ámbitos (animación turística, teatral, hospitalaria, deportiva, socio comunitaria...) y en varios sectores de población no exclusivos entre sí: infancia, juventud, tercera edad...

Al pretender incidir en diversos ámbitos de la vida de las personas y de las comunidades o debido a su carácter intergeneracional e interdisciplinar, se encuentran ciertas diferencias en su materialización práctica. Ello depende si se pone énfasis en lo educativo, social, cultural o económico.

Animación y Gestión, en la práctica, suelen obedecer a conceptos sensiblemente distintos de cultura. La primera maneja una visión amplia, imaginada y creada en la cotidianeidad de las personas, no estrictamente vinculada a las bellas artes o al ocio como parecen esenciales componentes de la segunda. La Animación Sociocultural potencia valores, hábitos y actitudes de compromiso social. Una concepción de cultura, esta, como patrimonio y meta común, al alcance de todos las personas, en el proceso de construcción de nuevas formas de relación, expresión y comunicación social.

\section{BIBLIOGRAFÍA}

Trilla, J. (coord.) (I997); Caride, J. A. (coord.) (2000); Calvo, A. (2000); Gómez, R. (dir.) (200o); Guillet, J.-C. (20o6); Pose, H. (2006); Ventosa, V. (coord.) (2006); Soler, P. (Coord.) (2OII). 


\section{Traducción}

[Traducción literaria/ literatura comparada/ texto literario/ competencia literaria]

\section{- Definición, antecedentes y actualidad del término}

La traducción es una actividad que consiste en comprender el significado de un texto en un idioma, llamado texto origen o «texto de salida», para producir un texto con significado equivalente, en otro idioma, llamado texto traducido o «texto meta».

El término traducción proviene del latín traducťo, -ōnis, «hacer pasar de un lugar a otro», y lo utilizó por primera vez Robert Estienne en I539, aunque ya en I44O, Leonardo Bruni había optado por el verbo traducere para ese mismo sentido. En latín clásico se solía hablar de translatio (traslación), versio (versión) o interpretatio (interpretación). A su vez, su significación está relacionada con los términos griegos $\mu \varepsilon \tau \alpha \phi o \varrho \alpha ́$ (metaforá, «tras-

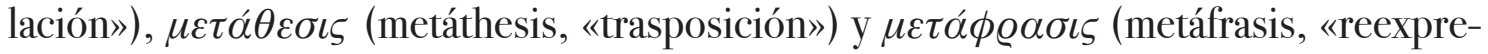
sión»).

A lo largo de la historia se han sucedido numerosas tentativas definitorias de la «traducción», con un marcado incremento a partir de la década de i96o y el auge de la Traductología como disciplina autónoma. Observamos cinco enfoques principales en este dilatado recorrido:

- Actividad entre lenguas: «pasar de una lengua A a una lengua B para expresar la misma realidad» (Vinay y Darbelnet), «enunciar en otra lengua lo que ha sido enunciado en una lengua fuente, conservando las equivalencias semánticas y estilísticas» (García Yedra).

- Actividad entre textos: «transmitir el sentido de los mensajes que contiene un texto» (Seleskovitch y Lederer), «la substitución de un texto en lengua de partida por un texto semántica y pragmáticamente equivalente en lengua meta» (House).

- Acto de comunicación: «reproducir en la lengua terminal el mensaje de la lengua original por medio del equivalente más próximo y más natural, primero en lo que se refiere al sentido, y luego en lo que atañe al estilo» (Nida), «un proceso comunicativo que tiene lugar en un contexto social» (Hatim y Mason).

- Proceso: «analizar la expresión del texto de Lengua Original en términos de oraciones prenucleares, trasladar las oraciones prenucleares de Lengua Original en oraciones prenucleares equivalentes de Lengua Término y, finalmente, transformar estas estructuras de Lengua Término en expresiones estilísticamente apropiadas» (Vázquez Ayora), «operación que consiste en determinar la significación de los signos lingüísticos en función de un querer decir concretizado en un mensaje, y restituir después ese mensaje íntegramente mediante los signos de otra lengua» (Delisle). 
- Actividad textual, comunicativay cognitiva: «un proceso interpretativo consistente en la reformulación de un texto con los medios de una lengua que se desarrolla en un contexto social y con una finalidad determinada» (Hurtado Albir).

\section{- Análisis}

La traducción constituye una actividad muy antigua. Una de las primeras evidencias escritas de traducción es la Piedra de Rossetta donde un mismo texto se encuentra en egipcio jeroglífico, egipcio demótico y griego, que sirvió para descifrar el significado de los jeroglíficos del antiguo Egipto.

Una parte significativa de la historia de la traducción en Occidente tiene que ver con la traducción de los textos bíblicos. Las primeras traducciones escritas atestiguadas provienen de la Biblia. Ptolomeo Filadelfo en el siglo III a. C. mandó traducir del hebreo al griego las Sagradas Escrituras a 72 sabios que dominaban el hebreo y el griego. Esta versión se conoce como versión alejandrina. A lo largo de los siglos I y II d. C., la Biblia se tradujo de manera intermitente del griego al latín. Este conjunto de textos se conoce como Vetus Latina.

El proceso traductor representa el proceso mental por el cual se permite transmitir un texto formulado en una lengua utilizando los medios de otra lengua. Históricamente se han distinguido en él tres procesos diferenciados: comprensión o análisis, desverbalización o representación y reexpresión o síntesis. Ciertos autores, como Delisle, añaden una fase más cuando se realiza exclusivamente por escrito: la verificación o revisión.

A diferencia de lo que se suele creer, dominar uno o varios idiomas no es condición suficiente para poder traducir a nivel profesional. Los idiomas no son sino una más de las herramientas necesarias para poder desempeñar con éxito la traducción. Traducir significa encontrarse en capacidad de comprender el sentido y reexpresarlo en otra lengua de manera efectiva y libre de las ataduras sintácticas de la lengua de origen; por lo que se distancia considerablemente de la mera sustitución de una palabra por otra.

Para un traductor el problema fundamental radica en la búsqueda de equivalentes que produzcan en el lector de la traducción el mismo efecto que el autor pretendía causar en el lector al que se dirigía el texto original. Esto le obliga a contemplar el texto, siempre desde el punto de vista de la traducción literaria, como la base de una continua "negociación" con el autor, para que el lenguaje del nuevo texto presente valores equivalentes a los del lenguaje original, sin olvidar ni sus elementos dinámicos, ni su calidad estética. Operación realmente de gran dificultad. Generalmente se acepta que no se traducen significados, sino mensajes, por lo que el texto deberá ser contemplado en su totalidad. 
Eugene A. Nida (I969) y (I975) distingue dos tipos de equivalencias: la equivalencia formal, en la que se reproducen mecánicamente en el texto de llegada las características formales del texto de partida, con la consiguiente distorsión de los patrones gramaticales y estilísticos que dificultan la comprensión por parte del receptor (se centra en la transformación del significado); y la equivalencia dinámica, en la que, conservando el mensaje, se busca que la respuesta del receptor de la traducción sea esencialmente la misma que la del receptor del original (se busca lograr igual efecto en el lector de la traducción que en el del original).

Su contribución más notable, y la más controvertida, a la teoría de la traducción, es la "equivalencia dinámica". El objetivo de este enfoque consiste en reproducir la intención del texto original en la traducción, en vez de limitarse a transcribir palabra por palabra el original. Nida también desarrolló la técnica del "análisis componencial”, que separaba las palabras en sus diferentes componentes con la finalidad de ayudar a determinar la equivalencia en la traducción.

Nida, Venuti o Steiner entre otros han demostrado que los estudios de traducción componen una disciplina más compleja de lo que pudiera parecer en un principio, ya que el traductor debe ver más allá del propio texto para deconstruir a un nivel intratextual y decodificar a un nivel referencial evaluando los elementos culturales específicos, la expresión idiomática y el lenguaje figurativo para lograr una comprensión del texto de partida y embarcarse en la creación de la traducción que no solo transfiere el significado de las palabras en un contexto determinado, sino además recrea el impacto del texto original dentro de los límites del sistema del propio lenguaje del traductor.

George Steiner (I975) propone un proceso hermenéutico (se va haciendo un recorrido con el bagaje cultural) que consta de cuatro etapas: la confianza inicial (en el texto original y en uno como traductor), el impulso de generosidad del traductor basado en la presuposición de que hay algo que merece comprenderse (hay un texto que vale la pena que otra cultura conozca); la agresión (con los cambios), la maniobra de comprensión que implica invasión y extracción; la incorporación, la importación de la significación (mensaje) y la forma (tratar de mantenerla), un acto que a veces modifica el origen; y la necesaria fase final de restauración del equilibrio (revisión).

En su influyente libro sobre la traducción Steiner deja bien patente que el acto de traducir instaura un proceso interpretativo. El estudio de la traducción va ligado al estudio del lenguaje, ya que desde el instante en el que comienza a hablar, todo lo que el ser humano hace es traducir: "interlingual translation is the main concern of this book, but it is between languages, human communication equals translation”. Defiende que la mejor traducción es la paráfrasis, entendida como movimiento hermenéutico para producir el texto que el autor hubiera escrito si lo hubiera compuesto en nuestra propia lengua. 
La traducción supone un concepto clave en cualquier disciplina, pero en el comparatismo resulta fundamental. El traductor personifica el auxiliar indispensable. Como remarcaba Guillén (I985) traducción y traducir, igual que diálogo y dialogar, se trata de conceptos que se prestan a la extensión y a la metáfora, y significan comprensión, interpretación y entendimiento. El concepto de traducción reafirma la noción de descentralidad, introduce una especie de correctivo a una interpretación excesivamente marcada en conceptos totalizadores como nación, obra o hasta escritor genial. Simboliza una puerta abierta a la interacción dialógica que ha de caracterizar la creación. La traducción nos muestra que el lenguaje de toda obra contiene un gran número de alusiones históricas y condicionantes sociales. Entonces, cuando cambiamos de sistema lingüístico y de lectores estos factores crecen espectacularmente. Traducir es introducir, leer y comunicar. Se trata una de las vías fundamentales de la transferencia literaria y cultural, pues abre una ventana a vientos diferentes y nuevos. Por tanto, la traducción se comprende como una acción innovadora y dialogal. Según comenta George Steiner, el traductor encarna uno de los motores de cambio de la literatura. El traductor, como intérprete de temas, de actitudes, de valores, en definitiva de nuevas perspectivas y contenidos culturales. La traducción es un acto de lectura y de interpretación profundo de un texto.

\section{BIBLIOGRAFÍA}

Ballester, J. (I999); Ballester, J. y Miralles, V. (I99I); Ballester, J. e Ibarra, N. (2008); Delisle, J. (เ980); García Yedra, V. (I982); Guillén, C. (I985); Hatim, B/Mason I. (I990); House, J. (I977); Hurtado Albir, A. (200I); Hutchins, W.J. (2000); Nida, E. A. (1975); Nida, E.A./Taber, C. R. (ı969); Mallafrè, J. (I99I); Steiner, G. (I975); Vega, M. A. (1994); Venuti, L. (I995). 


\section{Valores y lectura}

[Lectura crítica/ educación social]

\section{- Definición, antecedentes y actualidad del término}

Son muchos los autores que se han aproximado al concepto de valor y, en general, podemos hablar de cinco rasgos fundamentales en su definición. En este sentido, podemos entender un valor como: I) una creencia; 2) que pertenece a fines deseables o a formas de comportamiento;3) que transciende las situaciones específicas; 4) que guía la selección o evaluación de comportamientos, personas y sucesos; y 5) que se ordena por su importancia relativa a otros valores, para formar un sistema de prioridades de valores (Schwartz, I992, 200I; Schwartz y Bilsky, I987, I990).

El estudio de los valores nos sitúa en un ámbito complejo y difícil de caracterizar de forma precisa. Los valores serían abstracciones de lo que es importante y deseable, que sirven para juzgar y orientar nuestras acciones, y que han de entenderse "como creencias básicas a través de las cuales interpretamos el mundo y damos significado a los acontecimientos” (Yubero, Larrañaga y Cerrillo, 2004: IO). Debemos considerarlos realidades dinámicas, sometidas a cambios condicionados, en su manifestación y realización por el espacio y el tiempo. En términos generales, los valores han de entenderse como los criterios a través de los cuales se establece aquello que es deseable o no para una sociedad concreta, representando la esencia normativa por la que esa sociedad se rige. La determinación y el límite de los valores es una cuestión permanentemente abierta, como lo es la ciencia y la vida misma" (Nieto y González, 20O2: 29).

Los valores no son algo estático y pueden evolucionar a lo largo de la socialización del individuo. Nuevas circunstancias, informaciones o conflictos, pueden disminuir su importancia o aumentar su poder, del mismo modo que las actitudes son modificables a partir de la experiencia. La adquisición de valores se vincula inicialmente a la imitación de las conductas y comportamientos, siendo necesario, posteriormente, una fase de maduración en la que han de ser interiorizados para que constituyan un marco de referencia consciente.

La lectura forma parte de las prácticas más empleadas en la escuela, ocupando un papel fundamental dentro de la actividad escolar desde edades muy tempranas. La narración y la lectura de historias, con gran frecuencia, han formado parte del ritual de aprendizaje de valores sociales. De hecho, podemos considerar que la lectura es un valor en sí misma. Los cuentos que nos contaban de pequeños, los que nos leyeron posteriormente y los que hemos ido leyendo nosotros mismos a lo largo de nuestro proceso madurativo, han ayudado a nuestra construcción como personas. Podríamos decir que la mayoría de lecturas que forman parte de nuestro intertexto lector han sido, en gran medida, protagonistas 
de nuestro desarrollo como personas, estando estrechamente vinculadas al proceso de aprendizaje de los valores sociales propios de nuestra cultura y ayudándonos a formar parte del engranaje social.

\section{- Análisis}

El texto literario posee una serie de elementos denotativos y connotativos a través de los que los autores nos muestran el mundo, y buscan motivar nuestra capacidad reflexiva e interpretativa. Cuando un lector se introduce en un texto construye un cuadro mental sobre la narración, llega a identificarse con los personajes y las situaciones, y puede quedar inmerso emocionalmente con el texto. Además, los acontecimientos que transcurren en el relato, así como los personajes que cobran vida a través de las palabras, se convierten en experiencias vicarias, que pueden tener influencia en la orientación de nuestras actitudes y comportamientos, además de influir en nuestros propios juicios morales. El poder socializador de los relatos radica, por tanto, en su fuerza emotiva, en su capacidad para presentar nuestros propios miedos, sentimientos y conflictos internos.

Los valores sociales pueden aparecer representados en distintos niveles y estructuras del texto literario. Se pueden encontrar valores que se presentan como temas parciales y otros que lo hacen como temas globales. A partir de cada uno de estos dos tipos se establece una nueva distinción entre aquellos valores que aparecen representados en la $m i$ croestructura, lo que implica que dichos valores están explícitamente verbalizados en el texto, o bien los que aparecen en la macroestructura, en la que los valores no son citados literalmente, sino que se encuentran en las acciones que realizan los personajes.

Esta división se completa con las formas en que los valores se manifiestan en estas dos dimensiones del texto, considerando que en ambos casos los valores pueden aparecer de forma explícita, tanto en las oraciones del texto como en las actuaciones de un personaje, o de manera implícita, para lo que es necesaria una labor de interpretación y deducción, que determine su representación. Esta nueva división responde a la idea de que hay valores que aparecen como tales en los textos, pero otros se desprenden del texto tras cierta labor de deducción.

En esta clasificación los apartados son permeables y están comunicados, por lo que nada impide que un mismo texto contenga varias de estas categorías, de manera que nos podemos encontrar en una misma obra valores globales y parciales, valores representados en la macroestructura o en la microestructura, o valores manifestados a la vez de forma explícita y de forma implícita.

En el proceso de transmisión y recepción de valores a través de los textos narrativos adquieren gran relevancia los personajes. La caracterización de sus cualidades psicológi- 
cas, sus conductas y su forma de relacionarse, nos pueden ayudar a inferir gran parte de los valores sociales que el autor ha querido transmitir. Los personajes se convierten en modelos de conducta, cumpliendo no solo una función expresiva y representativa sino, además, modeladora. Las actitudes y comportamientos de los personajes en determinadas situaciones muestran al lector su posicionamiento ante los conflictos que se plantean, expresando así los valores predominantes en la historia. (Vid. Yubero, Larrañaga y Cerrillo, 2004: 39-64).

\section{- Implicaciones prácticas}

En el proceso de transmisión y recepción de valores a través de la lectura, partimos de las creencias y valores plasmadas por el autor del texto, de acuerdo a sus condiciones y convicciones, deudoras del momento y de las circunstancias en las que transcurre su propia vida. Este proceso finaliza con la figura del lector, quien "como receptor final de mensaje, procesa la información, añadiendo y eliminando aquellos elementos que no encajen en su propio proceso cognitivo" (Yubero, Larrañaga y Cerrillo, 2004: 9I). La clave del proceso de transmisión de valores a través de textos literarios reside, por tanto, en la diferenciación perceptiva de los distintos lectores. De manera que cada lector será el encargado de realizar su propia selección perceptiva dentro del contenido del propio texto, que estará basada fundamentalmente en sus experiencias, sus vivencias, sus aprendizajes y todos aquellos valores y creencias asimiladas a través de cualquier otro agente socializador.

No debemos magnificar la función ideológica o de transmisión de valores de los textos narrativos, ni pensar en efectos inmediatos o mecánicos de trasferencia entre los modelos presentados y los lectores. La lectura es una actividad cognitiva compleja, por lo que puede darse un proceso en el que los valores iniciales planteados por el autor del texto y seleccionados como adecuados por el propio educador, no sean percibidos de la misma manera por los lectores a los que van dirigidos. Por este motivo, para la educación en valores a través de la lectura, es imprescindible la figura de un mediador que lleve a cabo diferentes estrategias dirigidas a reconocer y analizar los valores contenidos, directa o indirectamente, en los textos.

A la hora de desarrollar estrategias para intervenir de forma intencionada sobre los procesos de adquisición de valores, es habitual la utilización de mecanismos de acercamiento a partir de los conocimientos, las emociones y los comportamientos. Existe gran variedad de estrategias para la educación en valores, si bien trabajos como los de Ortega, Mínguez y Gil (I996: 2O), Nieto y González (2002: 4I) y Yubero, Larrañaga y Sánchez García (2009: IO), coinciden en señalar los siguientes procedimientos como los más eficaces: 
a) Clarificación de valores: Identificación y reflexión razonable y consciente sobre aquello que se valora, se acepta o se piensa.

b) Discusión de dilemas morales: Presentación de historias conflictivas en las que la resolución implique una toma de decisiones sobre el valor que debe predominar.

c) Estudio de casos: A partir de la exposición de situaciones reales o ficticias se realiza su análisis, fomentando el intercambio de opiniones.

d) Análisis de valores y análisis crítico de la realidad: Estudio de problemas reales y sus consecuencias.

e) Comentario crítico de textos. Fomentar una visión crítica y analítica de los aspectos relevantes y significativos de un texto.

f) Autorregulación de la conducta. Conseguir el autocontrol de la conducta y la responsabilidad en la toma de decisiones.

El papel del mediador no debe ser el de imponer una lectura única y oficialmente legitimada, ni de evitar todo relativismo en la interpretación del texto, para guiar al lector a la identificación de unos valores determinados. El uso de las obras literarias para la educación en valores debe, por el contrario, favorecer el diálogo entre el lector y el texto, ayudándole a razonar sobre las vicisitudes de los personajes, a valorar o rechazar sus actos y a relacionar las conductas reflejadas en los textos con sus propias experiencias y valores.

\section{BIBLIOGRAFÍA}

Nieto, S. y González, J. (2002); Ortega, P., Mínguez, R. y Gil, R. (1996); Schwartz, S. H. (2OOI); Ros, M. y Gouveia, V. L. (coord.) (200I); Schwartz, S. H. (I992); Zanna, M. P. (comp.) (I992); Schwartz, S. H. \& Bilsky, W. (I990); Schwartz, S. H. \& Bilsky, W. (I987); Yubero, S., Larrañaga, E. y Cerrillo, P. (2004); Yubero, S., Larrañaga, E. y Sánchez García, S. (2009).

[S.Y.], [S.S.G.] y [E.L.] 